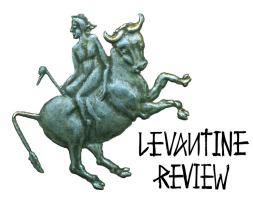

\title{
Turkmenistan and the Middle East
}

\author{
Michael B. Bishku*
}

\begin{abstract}
Turkmenistan is a weak country militarily, but well-endowed with natural gas reserves. While the latter also insulates it somewhat from international criticism of its human rights abuses, unfortunately, Turkmenistan is landlocked and dependent upon the goodwill of its neighbors in order to export that commodity. Additionally, Turkmenistan is in need of technological assistance. Given its relatively homogenous population and its hydrocarbon wealth it has adopted a policy of subsidizing certain necessities - though it underfunds other-and is fairly stable internally. Nevertheless, it is ruled under an autocratic political system, suffers massive corruption, and has to contend with fears of instability on its borders. Therefore, Turkmenistan has adopted a policy of permanent neutrality and is open to cooperation with all its neighbors as well as the big powers. The countries of the Middle East as both immediate and nearby neighbors play an important part in the international relations of Turkmenistan and in providing technological assistance and economic investments. This article, which reviews and analyzes those ties, utilizes government documents, academic works and newspapers from Turkmenistan and Middle Eastern countries.
\end{abstract}

Turkmenistan is a unique country. Unlike the other former Soviet Central Asian republics (Kazakhstan, Kyrgyzstan, Tajikistan and Uzbekistan,) Turkmenistan has joined neither the Russian-led Collective Security Treaty Organization (CSTO)—in which Uzbekistan suspended its membership in 2012-nor the Eurasian Economic Union (EEU,) established in 2014 and including Kazakhstan, Armenia and Belarus. Instead, Turkmenistan has declared a policy of permanent neutrality and is merely an "associate member" of the Commonwealth of Independent States (CIS.) ${ }^{1}$ At the same time, it is the most autocratic of the Central Asian states establishing cults of personality (of varying degrees) for Presidents Saparmurat Niyazov, known as Turkmenbashi (Head of the Turkmens) and who died in 2006, and Gurbanguly Berdymuhamedov, known as Arkadag (Protector) who has been ruler since then. Turkmenistan, the least populated of the Central Asian republics with just over 5 million inhabitants, is the most ethnically homogenous; about $85 \%$ of its citizens are Turkmens with Uzbeks and Russians accounting for $5 \%$ and $4 \%$ of the population

1 “CIS: Turkmenistan Reduces Ties to `Associate Member'." Radio Free Europe/Radio Liberty (RFE/RL), August 29, 2005. Available at: http://www.rferl.mobi/a/1061002.html. (Accessed on June 8, 2015.) 


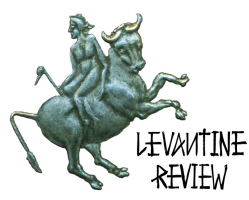

respectively. ${ }^{2}$ Turkmenistan is also Central Asia's largest country geographically-speaking, although more than two-thirds of its landmass lay in the Kara Kum Desert. The country is also blessed with the world's fourth largest reserves of natural gas-after Iran, Russia and Qatar in that order. ${ }^{3}$ Therefore, until recently Turkmenistan provided its citizens with free unlimited supplies of natural gas as well as with electricity and water. Energy subsidies in 2014 reportedly cost the government $\$ 5$ billion annually. ${ }^{4}$ Water is provided to drier areas of the country through the Kara Kum Canal, which is fed from the Amu Darya River in the northern part of the country and is shared with Uzbekistan. The canal was originally built in Soviet times to increase production of cotton, which is still an important export of Turkmenistan, albeit well behind natural gas and oil-an area in which the country is also self-sufficient. All together, cotton and energy constitute $90 \%$ of Turkmenistan's total exports. ${ }^{5}$

While Turkmenistan spends much money on infrastructure, including extravagant monuments dedicated to its leaders, especially in the capital, Ashgabat, located some 40 kilometers (about 25 miles) from the border with Iran, the state does not adequately fund

2 United States, Central Intelligence Agency (CIA), "Turkmenistan," The World Factbook. Available at: https://www.cia.gov/library/publications/the-world-factbook/geos/tx.html. (Accessed on June 6, 2015.) The other 6\% are of other ethnic groups. As for languages spoken in Turkmenistan, 72\% speak Turkmen, 12\% Russian and 9\% Uzbek.

3 This is according to the BP Statistical Review of World Energy, June 2014, p. 20. Available at: http://www.bp.com/content/dam/bp/pdf/Energy-economics/statistical-review2014/BP-statistical-review-of-world-energy-2014-full-report.pdf. (Accessed on June 6, 2015.)

4 Joao Peixe, "Free Energy Ride Over in Turkmenistan," OilPrice.com, January 20, 2014. Available at: http://oilprice.com/Energy/Energy-General/Free-Energy-Ride-Over-inTurkmenistan.html. (Accessed on June 6, 2015.)

5 Mark Horton and Jonathan Dunn, "Eurasia's Next Frontier," Finance \& Development, September 2013, p. 30. As Horton and Dunn are Assistant Director and Deputy Division Chief, respectively, in the International Monetary Fund's Middle East and Central Asia Department, the article is available on the IMF website at: http://www.imf.org/external/pubs/ft/fandd/2013/09/pdf/horton.pdf. (Accessed on June 6, 2015.) 


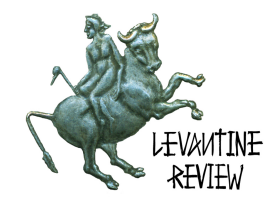

the education and health sectors. ${ }^{6}$ Moreover, according to government statistics, the country's average monthly salary in 2008 was only about $\$ 140$. $^{7}$

Unfortunately, Turkmenistan is landlocked so to speak, as the Caspian Sea, despite its name, is more of a lake than an "open sea" per se. However, due to its geostrategic location as well as its reserves hydrocarbons, Russia, China, the United States, the European Union and a number of countries in Asia and the Middle East have had a great interest in Turkmenistan. Therefore, like Azerbaijan, Turkmenistan is able to exercise some degree of political leverage, albeit to a lesser degree than its neighbor given the undetermined legal status of the Caspian Sea, Turkmenistan's dependence on hydrocarbon pipelines through the territory of its Central Asian neighbors and Russia, the instability in Afghanistan, and the sanctions regime that Iran had been subject to. Moreover, Turkmenistan needs to import a sizable amount of foodstuffs, and its military is much smaller in terms of personnel and equipment and far less funded than Azerbaijan's. Indeed, Turkmenistan is rated the weakest country militarily in Central Asia according to Global Firepower's 2015 rankings. ${ }^{8}$

With the preceding in mind, this article will examine Turkmenistan's relations with the countries of the Middle East, especially Turkey, Iran, the Arab states of the Persian Gulf, and finally Israel, a country to which Turkmenistan turned, in part, upon independence as a way to balance off Russia's influence due to past history and infrastructural arrangements in the region.

\section{Turkmenistan's Position in Central Asia and the World and the Mechanisms of Autocratic Rule}

Despite Turkmenistan's policy of permanent neutrality, which subsequently will be discussed in detail in this article, in the spring of 2015, there were unconfirmed reports

${ }^{6}$ According to the CIA, World Factbook, Turkmenistan's spending on health was $2 \%$ of Gross Domestic Product (GDP) in 2013, while on education it was 3\% of GDP in 2012. However, this source cautions that "The majority of Turkmenistan's economic statistics are state secrets. The present government established a State Agency for Statistics, but GDP numbers and other publicized figures are subject to wide margins of error."

7 “Average monthly salary in Turkmenistan totals \$140,” Turkmenistan.ru, April 15, 2008. Available at: http://www.turkmenistan.ru/en/print/node/6895. (Accessed on June 6, 2015.)

8 See the Global Firepower, "Comparisons of World Military Strengths," at their website: http://www.globalfirepower.com/countries-comparison.asp. (Accessed on June 6, 2015.) Out of 106 countries ranked, Azerbaijan is 63, while Turkmenistan is 90; Uzbekistan is the strongest in Central Asia ranked 54 followed by Kazakhstan at 66, Kyrgyzstan at 78 and Tajikistan at 81. 


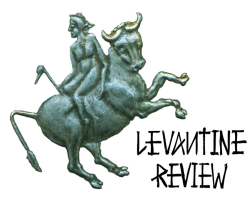

coming from a Turkmen exile website that Russia and Uzbekistan had sent troops to protect Turkmenistan's border from a perceived Islamic State threat from Afghanistan. ${ }^{9}$ However, said senior correspondent from Radio Free Europe/Radio Liberty (FRE/RL) Bruce Pannier: "the Turkmen government is so opaque and Turkmenistan is so closed off to foreigners, that no one can be sure what is happening." 10 What is certain, however, is that shortly before these reports appeared, the Russian CSTO Secretary General Nicolay Bordyuzha complained about Turkmenistan's (and Uzbekistan's) lack of cooperation on "common" security issues ${ }^{11}$ and that Turkmenistan had undertaken its "first large-scale mobilization of its reserve military forces since gaining independence." However, one reservist reached by telephone questioned the need: "Ours is a neutral country that nobody plans to attack."12 Nevertheless, about a year earlier, RFE/RL reported on a series of skirmishes with Taliban militants along Turkmenistan's border. ${ }^{13}$

In December 1991, Turkmenistan met with other former Soviet republics to establish the CIS, but did not ratify that organization's charter until over a year later. ${ }^{14}$ Nevertheless, Turkmenistan was and has continued-albeit in an associate member capacity since 2005-to be a participant at, as well as on occasion a host for, CIS meetings-as had been the case in November 2014 when CIS heads of government met in Ashgabat. However, that gathering received little media attention given the CIS's lack of importance in relation to such groups as the EEU and the Shanghai Cooperation Organization (SCO,) whose

9 Joshua Kucera, "Report: Troops from Uzbekistan and Russia Deployed to TurkmenistanAfghanistan Border," EurasiaNet.org, March 24, 2015. Available at: http://www.eurasianet.org/node/72686. (Accessed on June 8, 2015.)

10 Bruce Pannier, "Islamist Threat: Why is Russia Scaring Turkmenistan?" RFL/RE, April 14, 2015. Available at: http://www.rferl.org/content/qishloq-ovozi-turkmenistan-islamicmilitants-russia/26955023.html. (Accessed on June 8, 2015.)

11 Joshua Kucera, "Russia Frustrated by Refusal of Uzbekistan, Turkmenistan to Cooperate on Security," EurasiaNet.org, March 19, 2015. Available at:

http://www.eurasianet.org/node/72631. (Accessed on June 8, 2015.)

12 Joshua Kucera, “Turkmenistan Mobilizes Military against ISIS Threat," EurasiaNet.org, March 5, 2015. Available at: http://www.eurasianet.org/node/72411. (Accessed on June 8, 2015.)

13 Muhamad Tahir and Bruce Pannier, "Clashes, Appeasement, Isolation on the TurkmenAfghan Frontier," RFE/RL, March 6, 2014. Available at:

http://www.rferl.org/content/turkmenistan-afghanistan-taliban-bordersecurity/25288056.html. (Accessed on June 8, 2015.)

14 Turkmenistan, Ministry of Foreign Affairs, "Turkmenistan-CIS." Available at: http://www.mfa.gov.tm/en/turkmenistan-int-en/124-turkmenistan-cis. (Accessed on June 9, 2015.) 


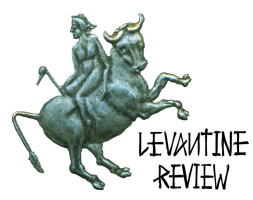

membership includes Russia, China and all the Central Asian republics except Turkmenistan, and in which Iran and Afghanistan hold observer state status. ${ }^{15}$

Years earlier, while Turkmenistan signed a Treaty of Friendship and Cooperation in July 1992 that allowed for Russian officers in the Turkmen army and for the joint defense of Turkmenistan ${ }^{16}$ - the last Russian troops (border guards) did not leave the country until December 200017 - Turkmenistan got the United Nations General Assembly to formally recognize its permanent neutrality in December 1995,18 two months after it joined the Non-Aligned Movement (NAM.) The only other former Soviet republics to become members of NAM, an organization that includes every Arab country and most of the Muslim world, have been Uzbekistan (1993), Belarus (1998,) and Azerbaijan (2011.) Permanent neutrality is also embodied in Turkmenistan's amended 2008 Constitution, but not the original one from 1992.

To Section 1, Article 1 of Turkmenistan's Constitution, the following passage was added in 2008:

Turkmenistan, by law, has the status of permanent neutrality. The United Nations General Assembly resolution "Permanent Neutrality of Turkmenistan" dated 12 December 1995: "1. Recognizes and supports the declared status of permanent neutrality of Turkmenistan; 2. Calls upon the member states of the United Nations to respect and support this status of Turkmenistan and also to respect its independence,

15 Chris Rickleton, "Turkmenistan: CIS Powwow Features Russian-Turkmen Horseplay," EurasiaNet.org, November 24, 2014. Available at:

http://www.eurasianet.org/node/71066. (Accessed on June 8, 2015.) Also see the SCO's website at: http://www.sectsco.org/EN123/.

16 Rainer Freitag-Wirminghaus, "Turkmenistan's Place in Central Asia and the World," in Post-Soviet Central Asia, Touraj Atatbaki and John 0'Kane, eds. (London: Tauris Academic Studies, 1998), p. 164. Freitag-Wirminghaus refers to Turkmenistan as a Russian "military protectorate" and notes that Turkmenistan paid for the maintenance of Russia's armed forces on its territory.

17 "Turkmenistan - Army," Global Security.org, last modified March 13, 2013. Available at: http://www.globalsecurity.org/military/world/centralasia/turkmen-army.htm. (Accessed on June 8,2015 .) Turkmenistan received arms for its military in return for shipments of natural gas.

18 See United Nations, General Assembly, A/RES/50/80, "Maintenance of International Security (A): Permanent Neutrality of Turkmenistan," December 12, 1995 at: http://www.un.org/documents/ga/res/50/a50r080.htm. (Accessed on June 8, 2015.) 


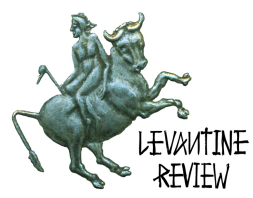

sovereignty and territorial integrity." The permanent neutrality of Turkmenistan, recognized by the world community, is the basis of its domestic and foreign policy. ${ }^{19}$

In Section 3, Chapter 2, Article 53 of the Constitution, the duties of the President of Turkmenistan are defined to include: 1) supervising the execution of foreign policy;2) serving as Supreme Commander of the Armed Forces; 3) presiding over the National Security Council; and 4) approving "the program and basic directions of the political, economic and social development of the country." These latter two duties were added to the 2008 Constitution, but Turkmenistan's first president Niyazov just like his successor Berdymuhamedov have ruled the country with an iron fist. Indeed, in 2001 Niyazov published a 400-page book called Ruhnama (Journal of the Soul) in which he "claimed to offer cultural and spiritual guidance" to all Turkmens and is described by noted author and journalist Dilip Hiro as "a hodgepodge of revisionist history, pedantic moralizing, petty philosophizing, and unsubstantiated claims." 20 The Ruhnama, which is composed of five sections-1) "Turkmen," 2) "The Turkmen's Path," 3) "Turkmen Nation," 4) "The State of Turkmen," and 5) "The Spiritual World of the Turkmen"- begins with the following words: "In the name of Allah, the Most Exalted. My Beloved People! My Dear Nation, This book [is] written with the help of inspiration sent to my heart by the God who created this wonderful universe, and is able to do whatever He wills." Afterwards, Niyazov claims that the Turkmen people founded more than 70 states and that its history goes back to the Prophet Noah who "gave the Turkmen lands to his son Yafes [in Turkish, Japheth in English or Yafet in Hebrew] and his descendants." 21

When Ruhnama was in preparation in 2000, one Turkmen government minister stated that it would "make up for the shortcomings in both the Bible and Koran." However, Niyazov asserted when it was published that it was "not a religious book."22 Nevertheless, Niyazov

${ }^{19} \mathrm{~A}$ text of the Constitution of Turkmenistan as amended on September 26, 2008 may be found at the World Intellectual Organization website:

http://www.wipo.int/wipolex/en/details.jsp?id=11374. To compare it with the text of the original 1992 Constitution see the University of Texas at Arlington website:

http://www.uta.edu/cpsees/TURKCON.htm. (Both accessed on June 9, 2015.)

20 Dilip Hiro, Inside Central Asia: A Political and Cultural History of Uzbekistan,

Turkmenistan, Kazakhstan, Kyrgyzstan, Tajikistan, Turkey, and Iran (New York: Overlook Press, 2009), p. 215.

${ }^{21}$ These quotations are from the Saparmurat Turkmenbashy "Ruhnama" website:

http://presidentniyazov.tripod.com/id66.html. (Accessed on June 4, 2015. Unfortunately, the links to the five sections were no longer functioning as of June 9, 2015.)

${ }^{22}$ Both this quote and the preceding one are from Sebastian Alison, "Ruhnama' is Required Reading," Moscow Times, September 17, 2002. Available at:

http://www.themoscowtimes.com/news/article/ruhnama-is-requiredreading/243591.html. (Accessed on June 9, 2015.) 


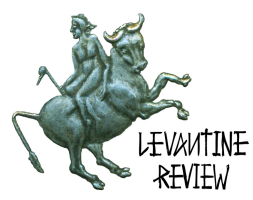

ordered that Ruhnama be prominently displayed as well as used in mosques and churches; it also was made part of school curriculum and knowledge of which could decide entrance into universities or becoming a civil servant, teacher or doctor. ${ }^{23}$ Berdymuhamedov removed the book from school curriculum in 2011, but it was not until three years later that familiarity with it was no longer required on university entrance exams. ${ }^{24}$ However, Berdymuhamedov, a dentist by training, now has his own books on medicine, health and famous horses as required reading. ${ }^{25}$ Upon assuming power, Berdymuhamedov reinstated the study of foreign languages in school, which was forbidden under Niyazov. He also increased the number of years of compulsory schooling, which had previously been reduced by his predecessor. ${ }^{26}$ At the same time, while Berdymuhamedov has allowed Turkmen students to study abroad, a certain number are not returning for various reasons including widespread internal corruption, lack of job opportunities, the possibility of being restricted from traveling abroad in the future, and "the desire to avoid harassment by the authorities," who tap telephones, monitor and restrict Internet usage and refuse to allow independent political parties and media. ${ }^{27}$

While Turkmenistan's domestic policies have been criticized by human rights groups, ${ }^{28}$ foreign governments have been more concerned with that country's hydrocarbon resources and its geostrategic location. As for Turkmenistan's policy of permanent neutrality, it is either beneficial or non-threatening to other countries. In an article in 1997 for Turkey's Ministry of Foreign Affairs' think tank, the Center for Strategic Research (SAM for Stratejik Araştırmalar Merkezi), Boris O. Shikhmuradov, then Deputy Prime Minister and Turkmenistan's Minister of Foreign Affairs, stated that while there have been many "projects to recognize the neutrality" of primarily European states since 1815 with Switzerland's Helvetic Union Affairs Declaration, he contends that that country was the

${ }^{23}$ Hiro, Inside Central Asia, pp. 216-217 and 225.

24 “Turkmenistan is Finally Putting `Ruhnama' Behind Them," Chronicles of Turkmenistan, August 6, 2014. Available at: http://www.chrono-tm.org/en/2014/08/turkmenistan-isfinally-putting-the-ruhnama-behind-them/. (Accessed on June 9, 2015.) Chronicles of Turkmenistan is an independent émigré news site.

25 Catherine A. Fitzpatrick, "President Berdymuhamedov's Report Card at Four Years," EurasiaNet.org, March 1, 2011. Available at: http://www.eurasianet.org/node/62977. (Accessed on June 9, 2015.)

${ }^{26}$ Hiro, Inside Central Asia, p. 230.

27 "Foreign Study Provides Escape for Turkmen Students," Institute for War \& Peace Reporting, January 12, 2013. Available at: https://iwpr.net/global-voices/foreign-studyprovides-escape-turkmen-students. (Accessed on June 9, 2015.)

${ }^{28}$ See for example Amnesty International Report, 2014-15: The State of the World's Human Rights, pp. 377-379. Available at: http://www.amnestyusa.org/pdfs/AIR15_English.PDF. (Accessed on June 9, 2015.) 


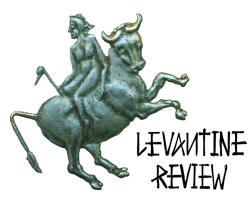

only one which "succeeded in keeping its neutral status," and that Austria's neutrality was only recognized in 1955 . However, according to Shikhmuradov,

The Turkmen model of neutrality radically changes the existing views on neutrality and, first of all, is based on modern international law, which is the law of peace. It may become the basis of a new concept of co-operation and progress for peace in the region. The proposed formula of stabilisation is vital for any society where human beings are declared to be of the highest value. For each individual, it means family and personal security, peace among friends, and peaceful labour.... For social strata and population groups it is mutual social understanding and support, absence of conflicts and of tension. For nations it means inner-and inter-ethnic consent and mutual understanding. For the state it means stability, guaranteed development, and the absence of wars and civil disasters. For the region it means geopolitical co-operation, reliable partnership, territorial immunity and security of borders. ${ }^{29}$

It should be noted that while Shikhmuradov lauds Niyazov's government earlier in the essay for providing Turkmenistan's citizens with a "guaranteed minimum of social and welfare provisions" in the country's transition to a market economy, such as subsidizing food and rent among other things, he subsequently became a political opponent of Niyazov and was arrested, along with 45 others, of an alleged plot to assassinate Turkmenistan's president in November 2002; he is, together with his successor as foreign minister, either still in jail-serving a life term in his case, while with his successor it is 25 years-or both may have died during incarceration. ${ }^{30}$

In 2005, on the tenth anniversary of the U.N. recognizing Turkmenistan's permanent neutrality - the day is celebrated as a national holiday-Niyazov gave a speech listing the "obligations" his country had assumed with such status:

1) it will not join political, economic, military alliances and blocs;

2) powers of the army will be limited to defending peace and freedoms;

${ }^{29}$ Boris Shikhmuradov, "Positive Neutrality as the Basis of Foreign Policy of Turkmenistan," Perceptions, Vol. 2, June-August 1997, p. 4. Available at: http://sam.gov.tr/wpcontent/uploads/2012/01/BORIS-O.-SHIKHMURADOV.pdf. (Accessed on June 10, 2015.) 30 Cheryl Collins, "Turkmenistan Revolves around President's Personality," Chicago Tribune, December 27, 2002; also, Antoine Blua, "Turkmenistan: Count Given Sweeping Powers to Sentence Would-Be Assassins," RFE/RL, January 17, 2003. Available at: http://www.rferl.org/content/article/1101936.html; and Arkady Dubnov, "Turkmenistan: Jailed Opposition Leaders Boris Shikhmuradov and Batyr Berduyev are Alive," Vremya Novostei (Moscow), September 27, 2007. Available at:

http://enews.fergananews.com/article.php?id=2141. (The latter two sources were accessed on June 10, 2015.) 


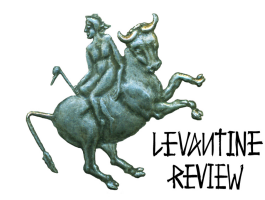

3) banning weapons of mass destruction and transportation of such weapons over land or air space of our country;

4) nobody has the right to force our state to join any military blocs and alliances;

5) all disputes in relations with foreign countries should be resolved through the UN;

6) adherence to common values, principles of democracy and ensuring domestic tranquility;

7) maintaining equal relations with all states regardless of their size;

8) all deeds and undertakings should be guided by humane principles and good intentions;

9) conducting its policy in close cooperation with international humanitarian organizations. $^{31}$

Obviously, with regard to some of the above issues, Turkmenistan's leader suffered from selective memory! However, he made a point to give special mention to two of the cosponsors of the U.N. General Assembly Resolution: Russia and the United States, in that order. Interestingly, in the essay by Shikhmuradov mentioned above, he emphasized that "support" for Turkmenistan's permanent neutrality came first from the Economic Cooperation Organization (ECO), whose members include Turkey, Iran, Pakistan, Afghanistan, Azerbaijan and all the other former Soviet republics in Central Asia; 32 and was "seconded" by a long list of countries including the People's Republic of China, Great Britain, France, Germany, Egypt, Israel, Malaysia and Indonesia among others. ${ }^{33}$

Today, China is quite important to Turkmenistan; it is that country's number one customer for natural gas thanks to a 1,140 mile long pipeline completed in December 2009 that travels through Uzbekistan and Kazakhstan to Xinjiang province. Early in 2015, Turkmenistan was complaining that Russia's state-run Gazprom, which has owned a 45\% share in Türkmengaz since 1995, was an "unreliable partner" as it was curtailing sharply gas purchases from Turkmenistan at the same time that country is facing increased competition in the China market from Russia. Hence, there is increased interest in the building of a trans-Caspian pipeline to supply Europe through Azerbaijan, Georgia and Turkey, something opposed by both Iran and Russia given disputes over sovereignty in the Caspian Sea and the fact that the latter country currently supplies one-third of Western Europe's gas needs. Moreover, Iran does not want a pipeline through its territory and Russia has voiced concerns that a trans-Caspian pipeline would pose an ecological threat to

${ }^{31}$ Quoted from "Neutrality is the Greatest Achievement of Our People," Speech by Saparmurat Niyazov on December 12, 2005. Available at:

http://presidentniyazov.tripod.com/id49.html. (Accessed on June 10, 2015.)

${ }^{32}$ See its website at: http://www.ecosecretariat.org/.

${ }^{33}$ Shikhmuradov, "Positive Neutrality," p. 3. 


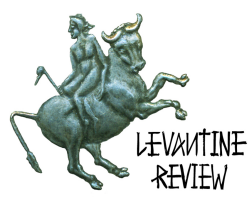

that body of water. ${ }^{34}$ At the fifteenth anniversary of the U.N.'s recognizing Turkmenistan's permanent neutrality, Berdymuhamedov noted

The space and scope of cooperation of Turkmenistan, which develops a dialogue on all geographical azimuths, considerably expanded at the bilateral level. In our field of view are the Asia-Pacific region, Europe, Americas and the Middle East. In parallel with development of cooperation with traditional partners of Turkmenistan, a dialogue with some large and economically strong countries in the Arab world and Latin America has been established in recent years. ${ }^{35}$

He referred to "our great neighbor in the east," the People's Republic of China as one of his county's "strategic partners," along with Russia, and stated that a "key priority of foreign policy" was the "promotion of brotherly relations" with Turkey, Iran, Azerbaijan, Afghanistan, Kazakhstan and Uzbekistan. In addition, Turkmenistan's ties with the Arab world, "including Saudi Arabia, the United Arab Emirates, Jordan and Qatar are brought to a qualitatively new level." Berdymuhamedov also attached "great importance" in developing further cooperation with the United States and the "intensification of political contacts" with the European Union as well as the "expansion of trade and economic cooperation." 36

In early 2015, the year of the twentieth anniversary, Turkmenistan's embassy in Afghanistan issued a statement in which it expressed the hope to see the construction,

${ }^{34}$ Chris Rickleton, “Turkmenistan Blasts Russia as an 'Unreliable' Gas Partner," EurasiaNet.org, February 17, 2015. Available at: http://www.eurasianet.org/node/72121; John C. K. Daly, “Turkmenistan's Lofty Ambitions for Natural Gas Exports,” Silk Road Reporters, February 24, 2015. Available at: http://www.silkroadreporters.com/2015/02/24/turkmenistans-lofty-ambitions-naturalgas-exports/; Jacopo Dettoni, "Turkmenistan Faces Competition from Russia as China's Largest Supplier," Nikkei Asian Review, January 14, 2015. Available at: http://asia.nikkei.com/Politics-Economy/International-Relations/Turkmenistan-facescompetition-from-Russia-as-China-s-largest-supplier; "EU: Turkmenistan Could Supply Europe with Natural Gas by 2019," Voice of America, May 3, 2015. Available at: http://www.voanews.com/content/eu-says-turkmenistan-could-supply-europe-with-gasby-2019/2747158.html; and "Introduction: Turkmenistan's Oil and Gas Industry," Russian Petroleum Investor, no date, but 2011 is most recent year mentioned in article. Available at: http://www.rpi-research.com/content/Sample_OG_Turkmenistan_eng.pdf. (All articles were accessed on June 10, 2015.) 35 Quoted from "Permanent Neutrality [of] Turkmenistan," Speech by Gurbanguly Berdymuhamedov on December 12, 2010. Available at:

http://www.turkmenistaninfo.ru/?page_id=6\&type=article\&elem_id=page_6/magazine_11 2/985\&lang_id=en\&layout=print. (Accessed on June 10, 2015.) 36 Ibid. 


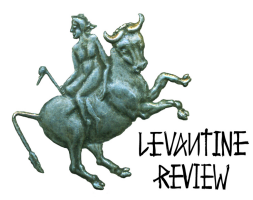

sometime soon, of the Turkmenistan-Afghanistan-Pakistan-India (TAPI) pipeline, which was first proposed in $1995 .^{37}$

\section{Turkmenistan's Relations with Turkey}

On February 29, 1992, Turkey became the seventh country in the world to establish diplomatic relations with Turkmenistan; it was preceded by Denmark, Iran, Afghanistan, Saudi Arabia, Great Britain and Bangladesh in that order. ${ }^{38}$ The breakup of the Soviet Union offered Turkey the "opportunity to find new sources of political and economic influence" and with regard to Central Asia-Tajikistan with its Persian background aside-the advantage of "similar ethnic, linguistic and cultural characteristics" as well as to provide a model of modernization in the Middle East with close relations to the West and a government, at the time, firmly committed to secularism. ${ }^{39}$

Indeed, the first line of Turkmenistan's Constitution states that it is a "secular state." Turkey had exaggerated expectations and the Central Asian states did not want to substitute a Soviet "big brother" for a Turkish one. Ankara established the Turkish International Cooperation and Coordination Agency (TİKA for Türk Isşbirliği ve Koordinasyon Ajansı) in January 1992. The organization's priority during the 1990s was Azerbaijan and Turkic Central Asia, but today it boasts offices in almost 40 countries in Asia, Africa and Eastern Europe, and is engaged in cooperative projects in 120 countries worldwide, providing aid of almost $\$ 1.3$ billion in $2011 .{ }^{40}$ Former Turkish President Abdullah Gül made a state visit to Turkmenistan in May 2013, accompanied by the minister of science, industry and technology, TİKA's president, members of parliament, journalists and businessmen, during which he was presented by his Turkmen counterpart Berdymuhamedov with the State Medal of Turkmenistan, the first ever given to a foreign head of state. There was also a groundbreaking ceremony for a new campus of the International Turkmen-Turkish University in Ashgabat (a Gülen movement institution still in operation) - the original one was opened in 1994-as well as the signing of a

37 "2015 is the Year of Neutrality and Peace in Turkmenistan," Kabul Times, February 6, 2015. Available at: http://thekabultimes.gov.af/index.php/opinions/politics/5755-2015is-the-year-of-neutrality-and-peace-in-turkmenistan.html. (Accessed on June 10, 2015.) 38 Turkmenistan, Ministry of Foreign Affairs, "States with which Turkmenistan Established Diplomatic Relations.” Available at: http://www.mfa.gov.tm/en/mfaen/diplomacy/diplomatic-relations. (Accessed on June 11, 2015.)

39 Sabri Sayarl. "Turkey, the Caucasus and Central Asia," in The New Geopolitics of Central Asia and Its Borderlands, Ali Banuazizi and Myron Weiner, eds. (Bloomington: Indiana University Press, 1994), pp. 176-180.

40 See its website at: http://www.tika.gov.tr/en. There are four departments: 1) Central Asia and Caucasus; 2) Middle East and Africa; 3) Balkans and Eastern Europe; and 4) East and South Asia, Pacific and Latin America. 


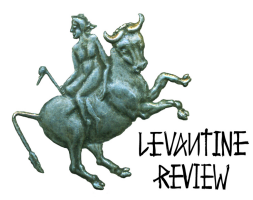

cooperation protocol for the search and restoration of the tomb of Alp Arslan, the second Seljuk Turkish leader (died 1072 C.E.) in Merv. ${ }^{41}$ TIKA has also been involved in the restoration of the Tombs of the Sahaba (companions of the Prophet Muhammad)-alHakam ibn Amra al-Gifari and Bureida ibn al-Huseiba al-Aslami-in the same city. ${ }^{42}$

As for education, Turkey has also provided scholarships for Turkmen students to attend Turkish universities, while the Gülen movement schools established throughout the country were closed by the Turkmenistan government-following the example of Uzbekistan-in 2011 except for Mustafa Kemal Atatürk School No. 57 in Ashgabat which was able to operate until 2014. Apparently, the latter action had the blessing and cooperation of the Turkish government due to the political fallout between the Gülen movement and the ruling Islamist AK Party, former allies, over a corruption probe of businessmen, relatives of politicians and bureaucrats connected with the AKP. This was also the case with regards to the school in Turkmenbashi, known during Soviet times as Krasnovodsk, located on the Caspian Sea, where teachers-a large number of whom were Turkish-and students were called "Wahhabists," a term used by officials in Central Asia for those who practice any form of Islam not sanctioned by the state. ${ }^{43}$ Over a decade

41 "President Abdullah Gül Pays an Official Visit to Turkmenistan." Available on the TİKA website at:

http://www.tika.gov.tr/en/news/president_abdullah_gul_pays_an_official_visit_to_turkme nistan-8680. (Accessed on June 11, 2015.) Sultan Alp Arslan was buried at one of three mosques: Ben-i Mahan, Mesjid-i Atik or Majan. See "Seljuk Sultan Alp Arslan's Tomb about to be Found in Merv, Say Experts," Daily Sabah (Istanbul), April 5, 2015. Available at: http://www.dailysabah.com/history/2015/04/05/seljuk-sultan-alp-arslans-tomb-aboutto-be-found-in-merv-say-experts. (Accessed on June 11, 2015.)

42 "TİKA Will Restore Tombs of the Sahaba in Turkmenistan." Available at the TiKA website at:

http://www.tika.gov.tr/en/news/tika_will_restore_tombs_of_the_sahaba_in_turkmenistan8616. (Accessed on June 11, 2015.)

43 Catherine A. Fitzpatrick, "Turkmenistan: Turkish Schools Closed Amid Concerns of Spread of Nurchilar Movement," EurasiaNet.org, August 22, 2011. Available at: http://www.eurasianet.org/node/64079; "Officials Close Down Turkish School in Ashgabat," Chronicles of Turkmenistan, August 20, 2014. Available at: http://www.chronotm.org/en/2014/08/officials-close-down-turkish-school-in-ashgabat/; and "Turkish Schools are Being Closed Down," Today's Zaman, April 10, 2014. Available at: http://www.todayszaman.com/turkish-press-review_turkish-schools-are-being-closeddown_344269.html. (All articles were accessed on June 11, 2015.) According to the last article, Then-"Foreign Minister Ahmet Davutoğlu stated he had ordered the closure of Turkish schools in 160 countries, arguing that the officials of those schools had sent letters to the leaders of foreign countries in which they complained about the Turkish government." 


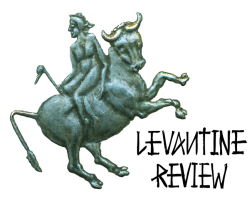

before these closures, journalist Hugh Pope noted that in Turkmenistan local elites "crowded [the Gülen movement] schools with applications for the few places available" and that the curricula "stressed national pride more than any overt religious agenda," with just an hour a week spent on instruction in the "history of religions." As for the university, Pope relates enthusiastically that the tuition in 2000 was no more than $\$ 15$ a month and the place was "pristinely kept." During a visit there, Pope met a secular "businessman who was helping to finance the place" and who pointed out with great pleasure when they left campus "the projects in which Turks from Turkey had taken a leading role-hotels, the airport, shops, cars and even the roads." ${ }^{4}$ Moreover, Dilip Hiro notes that rumor had it that Niyazov and his family were beneficiaries of export trade involving Turkish companies. ${ }^{45}$ Nevertheless, while Turkish firms have been engaged in a great deal of construction in Turkmenistan, there have been a fair number of problems; in 2011 there were disputes over about $\$ 1$ billion in payments for Turkish construction projects as well as lawsuits involving about 20 companies. 46

Obviously, business connections between Turkey and Turkmenistan are of great importance as Turkish Airlines is just one of a handful of foreign carriers that fly to Ashgabat - the others are Flydubai, Lufthansa, Russia's S7, and Belarus' Belavia.47 Turkmenistan Airlines, on the other hand, flies to about a dozen and a half places mostly in Europe, including Russia's and Ukraine's two largest cities, Minsk, London, Paris and Frankfurt, and some in Asia, including Beijing, Almaty, Delhi and Bangkok as well as the Middle Eastern cities of Istanbul, Dubai and Abu Dhabi; likewise, Turkmenistan's national carrier advertises on its website that it will soon be flying to Ankara. ${ }^{48}$ As for trade, according to the CIA Factbook, in 2013, Turkey was Turkmenistan's second largest export partner at a mere 5\% of the share with China at 68.3\%; at the same time, Turkmenistan's import partners, were more varied, with Turkey leading at $22.3 \%$ of the share, followed by Russia at 15.3\%, China at 13\%, the United Arab Emirates (UAE) at 6.8\%, Ukraine at 6.3\%, and Germany at $6 \% .{ }^{49}$ As Turkmenistan's chief exports are gas, crude oil, textiles and cotton fiber, and given the current routes of energy pipelines, railroads, roads, and air links,

${ }^{44}$ Hugh Pope, Sons of the Conquerors: The Rise of the Turkic World (New York: Overlook Duckworth, 2005), pp. 257-258.

45 Hiro, Inside Central Asia, p. 207.

46 Fitzpatrick, "Turkish Schools Closed."

47 See the Advantour website: http://www.advantour.com/turkmenistan/flights.htm. The company conducts tours in Central Asia and is more up to date than Skyscanner, which does not list flydubai, the newest entrant to that market. Also see the Turkish Airlines website: http://www.turkishairlines.com/; and the flydubai website:

http://www.flydubai.com/en/. (All accessed on June 11, 2015.)

${ }^{48}$ See the Turkmenistan Airlines website: http://turkmenairlines.com/. (Accessed on June 11, 2015.)

${ }^{49}$ See endnote 6. 


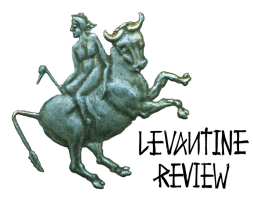

it is easy to figure out what is going where, with Russia, the other Central Asian states, Iran and Afghanistan obviously accounting for most of the remainder of Turkmenistan's exports. As for Turkmenistan's chief imports of machinery and equipment, chemicals and foodstuffs, these items can either come from any of Turkmenistan's partners or in the case of the UAE be a point of transfer.

\section{Turkmenistan's Relations with Iran and the Rest of the Muslim World}

On February 18, 1992, Iran established diplomatic relations with Turkmenistan; Saudi Arabia did the same three days later, while most countries in the Arab and Muslim worlds followed suit over the next couple of years. In an obvious attempt to curry favor with those countries, in April 1992, Niyazov made an umra, a short pilgrimage to Mecca. However, Iran developed the closest relationship with Turkmenistan especially during Niyazov's presidency, and, over the years, there have been many high-level diplomatic visits between the two countries. Unlike in Azerbaijan, which has a large population of Shi'a Muslims, Iran has had no Islamic agenda in secular, but nominally Sunni, Turkmenistan. Instead, Iran has emphasized trade and mutually beneficial infrastructural projects and as a result of geography, and views Turkmenistan "as a bridge to the rest of Central Asia." 50 In December 1997, Niyazov and his Iranian counterpart Muhammad Khatami opened the Korpedze-Kord Kuy natural gas pipeline between the deposits in western Turkmenistan and the Iranian city near the Caspian Sea. The $\$ 195$ million project, built by Iran's National Oil Engineering and Construction Company, covers a mere 200 kilometers (about 125 miles,) but was the first pipeline constructed in a direction outside the former Soviet Union and connected with Iran's national network. At the opening ceremony, which was Khatami's first trip abroad since being elected president of Iran, he stated that the project was

an indication of Iran's goodwill to promote cooperation with neighbouring countries [and] for the first time allows Turkmenistan to export gas since its independence. [The pipeline] will reinforce the pillars of Turkmenistan's independence. The Islamic Republic of Iran takes pride in taking steps towards economic development in neighbouring Turkmenistan. ${ }^{51}$

Niyazov also praised cooperation between the two countries mentioning specifically the construction of the Mashad-Serakhs-Tedzhen railway-the latter two cities are in

50 Alex Vatanka, “Does Iran have a ‘bridge' to Central Asia?” Al-Monitor, March 18, 2015. Available at: http://www.al-monitor.com/pulse/originals/2015/03/iran-turkmenistanrouhani-kazakhstan.html\#. (Accessed on June 13, 2015.) This sentiment was stated by an Iranian ambassador to the region.

51 "World: Monitoring Iranian Media Reports on New Gas Pipeline," BBC News, December 29, 1997. Available at: http://news.bbc.co.uk/2/hi/world/monitoring/43226.stm. (Accessed on June 13, 2015.) 


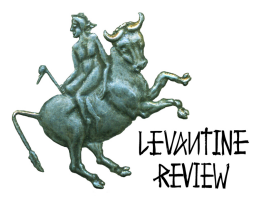

Turkmenistan-completed in May 1996 linking the Iranian and Central Asian rail networks, while Khatami emphasized a new fiber-optic communications line. The day before, the Iranian leader had received an honorary degree from Turkmen Makhtumkuli State University in Ashgabat. 52

In June 2007, when Turkmenistan's president Berdymuhamedov visited his Iranian counterpart Mahmud Ahmedinejad in Tehran, the Turkmen media described the two leaders as "the best of friends." However, by December, talks with Iran over increased gas prices broke down, and the following month, in the depth of winter, Turkmenistan cut supplies, blaming the disruption on maintenance of the pipeline. (By 2012, Iran was buying about a third of Turkmenistan's exports for heating and for use in industry distant from its own fields near the Persian Gulf.) Naturally, Iranian gas shipments to Turkey were curtailed. The crisis was settled when Turkmenistan agreed to build a second shorter gas pipeline from Dovletabad, in the eastern part of the country close to the Iranian border. The project was completed in December 2009.53

In December 2014, the final link in a north-south rail corridor connecting Kazakhstan Turkmenistan and Iran was completed-the two first two countries opened their connection in May-after five years of construction. The rail line in addition to transporting passengers carries oil and agricultural produce. Turkmenistan's portion of the tracks, the longest size-wise, was financed by the Islamic Development Bank-affiliated with the Organization of Islamic Cooperation, initiated by Saudi Arabia and in which Turkmenistan is a member. Other financial backing also came from the Saudi Fund for Development, the Abu Dhabi Fund for Development, and the Asian Development Bank. ${ }^{54}$ While Saudi Arabia's airline, Saudia, does not have service to Ashgabat, Flydubai has flights between the capital of Turkmenistan and Abha, located in Asir province in the southwestern part of Saudi Arabia, a tourist destination with a mild climate due to its elevation.

On March 10-11, 2015, Iran's President Hassan Rouhani made an official visit to Ashgabat during which time he and Berdymuhamedov signed 17 cooperative agreements dealing with political, economic and cultural issues. The Iranian leader pledged to increase annual

\footnotetext{
52 Ibid.

53 Bruce Pannier, “Turkmenistan/Iran: Good Relations Take Turn for the Worse," $R F E / R L$, January 15, 2008. Available at: http://www.rferl.org/content/article/1079354.html; and "Turkmenistan Set for Gas Shipments to Iran," UPI.com, August 14, 2009. Available at: http://www.upi.com/Business_News/Energy-Resources/2009/08/14/Turkmenistan-setfor-gas-shipments-to-Iran/51341250272665/. (Both accessed on June 13, 2015.)

54 "Iran-Turkmenistan-Kazakhstan Rail Link Inaugurated," Railway Gazette, December 4, 2014. Available at: http://www.railwaygazette.com/news/news/asia/singleview/view/iran-turkmenistan-kazakhstan-rail-link-inaugurated.html. (Accessed on June 13, 2015.)
} 


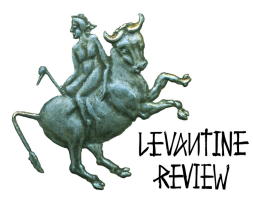

trade from $\$ 3.7$ billion to $\$ 60$ billion within a decade and agreed to cooperate in security matters and in fighting drug traffic from Afghanistan. ${ }^{55}$ In fact, Berdymuhamedov had met with Iran's minister of defense the previous September, on the heels of an earlier brief meeting between the Turkmenistan and Iranian leaders in Tajikistan. ${ }^{56}$ At the same time, as Russia's Gazprom has been in the process of cutting Central Asian gas imports, Turkmenistan was looking for additional export markets. And so, Berdymuhamedov would meet with his Turkish counterpart, Recep Tayyip Erdoğan, in Ankara on March 4, 2015. A few months earlier Erdoğan had made his first trip to Ashgabat as president, on November 6-7, to discuss bilateral energy cooperation as well as well as other issues. ${ }^{57}$ Meanwhile, a trilateral meeting of the foreign ministers of Turkmenistan, Turkey and Azerbaijan took place in Ashgabat in January 2015 as part of a process, according to the Turkish newspaper Today's Zaman, which was initiated in May 2014 "in order to deepen already strong historical, cultural and economic ties in light of new developments in global politics."58 Obviously, this is a reference to Russia's occupation of Crimea and the instability in the Middle East caused by the rise of the Islamic State. An immediate economic goal is to diversify transportation routes in order to reduce costs-as Iran had increased fees on Turkish trucks transiting the country-and increase capacity for the shipment of goods. Turkey's International Transporters Association (UND for Uluslararası Nakliyeciler Derneği) favors transit routes across the Caspian Sea between Turkmenbashi, Turkmenistan and Baku, Azerbaijan. ${ }^{59}$ Meanwhile, Russia and Iran would oppose a transCaspian pipeline favored by the European Union, Turkey and Azerbaijan.

\section{Turkmenistan's Relations with Israel}

On October 8, 1993, Israel established diplomatic relations with Turkmenistan, a year and a half after the Palestinian Authority had done so (on April 17, 1992.) However, the

\footnotetext{
55 Vatanka, “Does Iran have a 'bridge’ to Central Asia?”

56 "Turkmen Leader Meets with Iranian Defense Minister in Ashgabat," RFE/RL, September 17, 2014. Available at: http://www.rferl.org/content/turkmen-iran-berymukhammedovdefense-talks-tehran-ashgabat/26590160.html. (Accessed on June 13, 2015.)

57 Zaur Shiriyev, “Turkmenistan, Turkey and Azerbaijan: A Trilateral Energy Strategy?” Eurasia Daily Monitor, Vol. 12, Issue 45 (March 11, 2015.) Available at: http://www.jamestown.org/single/?tx_ttnews[tt_news]=43646\&tx_ttnews[backPid]=7\&c Hash=a79ddb4bdb31ed4e48c3832c0a85ced8\%23.VQXtNGb6nLU\#.VXzQ2kb09dB. (Accessed on June 13, 2015.)

58 Salim Avcl, "Turkey Focuses on Deepening Ties with Allies in Central Asia amid Changing Outlook in World," Today's Zaman, March 7, 2015. Available at:

http://www.todayszaman.com/national_turkey-focuses-on-deepening-ties-with-allies-incentral-asia-amid-changing-outlook-in-world_374579.html. (Accessed on June 13, 2015.) 59 Ibid.
} 


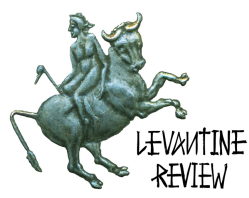

Palestinian Authroty has no embassy in Ashgabat, and Israel did not decide to open one until May 2009. At that time, the Israeli Foreign Ministry announcement stated that:

Turkmenistan is one of the leading countries in Central Asia, and Israel's relations with it are of political, economic and strategic importance. We are certain that the permanent presence of an Israeli diplomat at the ambassadorial level in Ashgabat will ensure an additional quantum leap in the development of relations with a pivotal and friendly country such as Turkmenistan. ${ }^{60}$

Prior to that Israel's relations with Turkmenistan were generally handled through a nonresident ambassador based in Jerusalem. However, its first two resident ambassadorial designates were both delayed for months as a "diplomatic hint," and in the case of the second, his name was rejected outright by the Turkmenistan government. The first, Reuven Dinel, was an alleged former Mossad agent who had worked at the Israeli embassy, and was expelled from Russia in 1996 on suspicion of engaging in espionage. The second ambassador designate was Haim Koren, a former instructor at Israel's National Security College in Glilot. In the case of Koren, a senior Turkmen official reportedly told his Israeli counterparts "we want you to send us an ambassador who will deal with bilateral relations, not a spy to collect intelligence on Iran."61 Finally, Israel chose Shemi Tzur, a career diplomat who had served previously as chargé d'affaires in Uzbekistan and as ambassador in Cyprus, Finland and New Zealand. Tzur presented his credentials in Ashgabat in June 2013.62 In January 2015, Yitzhak Carmel Kagan, who was formerly Deputy Ambassador to Ukraine, was chosen to succeed Tzur. Since February 2014, Serdarov Ata Oveznepesovich, Turkmenistan's ambassador to Turkey, also serves in a non-resident ambassadorial capacity to Israel. ${ }^{63}$

60 Israel, Ministry of Foreign Affairs, "Israel to Open Embassy in Turkmenistan," May 20, 2009. Available at: http://mfa.gov.il/MFA/PressRoom/2009/Pages/Israel-to-openembassy-in-Turkmenistan-20-May-2009.aspx. (Accessed on June 13, 2015.)

${ }^{61}$ Barak Ravid, "Turkmenistan Rejects Israeli Ambassador, Says He is `Mossad Spy,” Haaretz, July 7, 2011. Available at: http://www.haaretz.com/printedition/news/turkmenistan-rejects-israeli-ambassador-says-he-is-mossad-spy-1.371845; and "Turkmenistan: Ashgabat Stalls on Israeli Ambassador," EurasiaNet.org, March 1, 2010. Available at:

http://www.eurasianet.org/departments/news/articles/eav030210b.shtml. (Both accessed on June 13, 2015.)

62 “Israeli Ambassador Accredited in Turkmenistan," Turkmenistan.ru, June 6, 2013. Available at: http://www.turkmenistan.ru/en/articles/17262.html. (Accessed on June 13, 2015.)

63 Greer Fay Cashman, "Peres Greets New Envoys from Hungary, Turkmenistan, Micronesia, and Serbia," Jerusalem Post, February 3, 2014. Available at: 


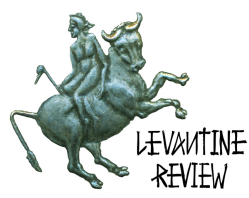

Unlike in neighboring Uzbekistan or Kazakhstan, where Jews have historically had more of a presence, there were about 3,000 Jews in Turkmenistan at the time of the collapse of the Soviet Union. Today, a mere 700 Jews remain, primarily in Ashgabat, where the only synagogue in the country had been converted into a gymnasium during Soviet times. ${ }^{64}$ Despite the fact that Niyazov's wife Muza Sokolova was a Russian of Jewish background, ${ }^{65}$ Turkmenistan was reluctant during the 1990s, to normalize relations with Israel, as it was concerned with reaction from Iran. ${ }^{66}$ Indeed, on a visit to Tehran in July 1998, Ayatollah Khamenei expressed his opposition to Niyazov concerning Israeli aid or investment in Caspian Sea development projects as it would be "detrimental for regional security" and particularly for Iran. ${ }^{67}$ Nevertheless, Israel and Turkmenistan signed an "Agreement for the Promotion and Reciprocal Protection of Investments" in Jerusalem in May 1995.68 During the years Niyazov was in power, the most instrumental figure in promoting Israeli economic interests in Turkmenistan was Yossi Maiman, owner of the Merhav Group of companies. In Turkmenistan itself, Merhav was involved in some important projects in the energy sector and chemical industry such as the renovation of an oil refinery and the construction of a polypropylene factory in Turkmenbashi; investments that by 2007 were estimated to be about $\$ 1.7$ billion. ${ }^{69}$ However, neither Merhav nor any Israeli companies have had much success with Berdymuhamedov. This was most probably one of the reasons for the timing of the decision to establish an Israeli embassy in Ashgabat.

In November 2011, Turkmenistan backed out on a $\$ 300$ million deal with an Israeli company to purchase satellites for both civilian and military use. This marked about a

http://www.jpost.com/Diplomacy-and-Politics/Peres-greets-new-envoys-from-HungaryTurkmenistan-Micronesia-and-Serbia-340222. (Accessed on June 13, 2015.)

64 See the website for the Jewish Virtual Library, "Turkmenistan," at: http://www.jewishvirtuallibrary.org/jsource/vjw/Turkmenistan.html. (Accessed on June 13, 2015.)

65 Hiro, Inside Central Asia, p. 198.

${ }^{66}$ Jacob Abadi, Israel's Quest for Recognition and Acceptance in Asia: Garrison State Diplomacy (London: Frank Cass, 2004), p. 440.

67 Boston University, Institute for the Study of Conflict, Ideology and Policy, Editorial Digest, Vol. 3, No. 11 (August 3, 1998.) Available at:

http://www.bu.edu/iscip/digest/vol3/ed0311.html. (Accessed on June 14, 2015.)

68 The text of which may be found on the United Nations Conference on Trade and Development website:

http://investmentpolicyhub.unctad.org/Download/TreatyFile/1677. (Accessed on June 14, 2015.)

69 Boston University, Editorial Digest, August 3, 1998; and Lior Bar-On, "Merhav Proposes \$3b Investment in Turkmenistan," Globes: Israel Business Arena, April 11, 2007. Available at: http://www.globes.co.il/en/article-1000200572. (Accessed on June 14, 2015.) 


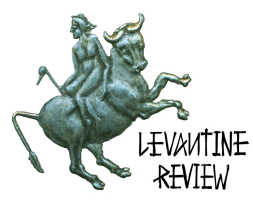

decade without any Israeli weapons sales to Turkmenistan. ${ }^{70}$ Yet, later in the month, the United Nations Development Program in Turkmenistan and Israel's Agency for International Development Cooperation (MASHAV) signed a memorandum of understanding to work together on development efforts in Turkmenistan. Unfortunately, the Israeli agency's programs for Turkmenistan were very modest in comparison with those in neighboring Kazakhstan and Uzbekistan. ${ }^{71}$

Despite some bilateral disputes, including the ambassador designate snafu mentioned above, Turkmenistan was absent for a United Nations vote on Palestine's full membership in UNESCO in November 2011. ${ }^{72}$ However, a little over a year later, Turkmenistan voted at the UN, alongside the majority, to accord Palestine a "Non-Member Observer State" status in that world body. ${ }^{73}$ Turkmenistan like all the other countries in Central Asia believes in a two-state solution for the Israel-Palestine conflict, and although there is no Palestinian embassy in Ashgabat, the Turkmenistan government consults with Palestinian officials periodically. To wit, in April 2012, when the Palestinian Authority's ambassador to Azerbaijan visited Turkmenistan's capital, he was informed that that country "attaches particular importance to the establishment of open international dialogue aimed at strengthening general peace, security and stability."74

\section{Conclusion}

70 Catherine A. Fitzpatrick, "Israel's Troubles in Turkmenistan," EurasiaNet.org, November 7, 2011. Available at: http://www.eurasianet.org/node/64467. (Accessed on June 14, 2015.)

71 See Michael B. Bishku, "The Relations of the Central Asian Republics of Kazakhstan and Uzbekistan with Israel," Middle Eastern Studies, Vol. 48, No. 6 (November 2012), pp. $927-$ 940; “UNDP in Turkmenistan and Israeli Agency for International Development Cooperation Sign Cooperation Agreement," United Nations in Turkmenistan, November 26, 2011. Available at: http://www.untuk.org/content/view/671/1/; and MASHAV's website: http://mashav.mfa.gov.il/MFA/mashav/Pages/default-old.aspx. (Both accessed on June 14, 2015.)

72 "How UNESCO countries voted on Palestinian membership," Guardian (London), November 1, 2011. Available at: http://www.theguardian.com/world/2011/nov/01/unesco-countries-vote-palestinianmembership. (Accessed on June 14, 2015.)

73 The text of the resolution United Nations, General Assembly, GA/11317, November 29, 2012 is available at: http://www.un.org/press/en/2012/ga11317.doc.htm. (Accessed on June 14, 2015.)

74 "Turkmenistan, Palestine discuss cooperation issues," Trend News Agency (Baku), April 6, 2012. Available at: http://en.trend.az/casia/turkmenistan/2011197.html. (Accessed on June 14, 2015.) 


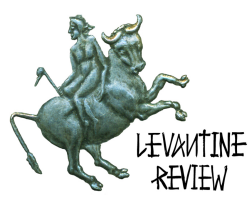

Turkmenistan is a weak country militarily, but well-endowed with natural gas reserves. While the latter also insulates Turkmenistan to some extent from international criticism of its human rights abuses, unfortunately, the country is landlocked and as such dependent upon the goodwill of its neighbors in order to export its products. Additionally, Turkmenistan is in need of technological assistance. Given its relatively homogenous population, and its rich hydrocarbon reserves, Turkmenistan has adopted a policy of subsidizing certain necessities-though it underfunds others - and is fairly politically stable internally. Nevertheless, Turkmenistan remains an autocratic polity with an autocratic political system, plagued by massive corruption and preoccupied with possibilities of instability on its borders. Therefore, Turkmenistan has adopted a policy of permanent neutrality, and is open to cooperation with all its neighbors as well as the big powers. The countries of the Middle East as both immediate and nearby neighbors play an important part in the international relations of Turkmenistan and in providing technological assistance and economic investments.

\footnotetext{
* Michael B. Bishku is a Professor of History at the University of Augusta in Georgia. He is a former President of both the American Council for the Study of Islamic Societies and the Association of Third World Studies, and is currently one of the Advisory Editors for Oxford University Press' Online Bibliographies for the Islamic World.
} 